\title{
Ethiopian and Eritrean Askaris in Libya (1911- 1932)
}

\author{
Dechasa Abebe ${ }^{1}$
}

\begin{abstract}
A number of books and articles were published on the three consecutive Italian wars in Libya and its resistances during the first three decades of the twentieth century. However, the role and experiences of the Ethiopian and Eritrean askaris were rarely studied. Thus, this article is an attempt to disclose their role in the wars, why they were interested in being employed by the Italians and why Italy relied heavily on them instead of the Italian soldiers and the Libyan askaris. Historical sources, like the memoires of Italian military commanders and the askaris, travellers' accounts mainly that of journalists, correspondence documents, and popular songs particularly that of Tigrigna were consulted to write this article. Moreover, publications produced by military historians on the Italian wars in Libya were also referred. While starvation and famines, poverty, unemployment and maladministration were the driving force from Eritrea and Ethiopia; salary, military uniform, guns and bullets, rations, protections and relative freedom were some of the attractions from the Italian side for the Ethiopians and Eritreans to be employed as askaris. In relation to these, political expediency or loss aversion, cost, fighting skill and courage, adaptability to Libyan topography and loyalty were some of the qualities of Ethiopians and Eritrean askaris that initiated the Italians to rely on. As a result, about 68 battalions fought in the wars. In the process, the askaris were identified by their Italian commanders as "warlike race" and best soldiers in contrast to the Italian soldiers and Libyan collaborators.
\end{abstract}

Keywords: Askaris, Mercenaries, Resistances, Libyans, Italians

DOI: https://dx.doi.org/10.4314/ejossah.v13i2.2

${ }^{1}$ Assistant Professor, Center for African and Oriental Studies, Addis Ababa University, Email: dechasa.abebe@aau.edu.et or abebedechasa@yahoo.com, Tel: +251911798518, P.O. Box: 150053/ Addis Ababa

This work is licensed to the publisher under the Creative Commons Attribution-NonCommercialNoDerivs License. 


\section{Background}

The term Libya is an Egyptian word that refers to the region of North Africa as to the thought of the Greeks and only to Cyrenaica as to that of the Romans. In fact, there are also sources that indicate it is a Greek name for the Berbers of North Africa inhabiting the area west of Egypt. It was to mean light skinned people in contrast to the term Sudan or Ethiopia to mean the blacks (Raza, 2012: 1; Shillington, 2005: 63). It was begun to be used for the present territory of Libya by the Italians since November, 1911. Modern Libya is a country which was founded in 1951 by unifying three territories of Northern Africa; Tripolitania, Cyrenaica and Fezzan (Raza, 2012: 2). Throughout most of its history, Libya was subjected to foreign rule, probably because of its proximity to the continental Europe and the Middle East. It was also the destination of long distance trans-Saharan trade route from west Africa to north Africa, particularly up to the end of the $15^{\text {th }}$ and beginning of the $16^{\text {th }}$ centuries. Then, the trade route was diverted to the Atlantic because of the opening of the Atlantic trade route to the "new world". Therefore, Libya was affected continuously by foreign cultures at least since the time of "classical civilization" of the Mediterranean world in the late BCs and early ADs. The major actors in these continuous influence and cultural dominance were the Phoenicians, the Greeks, the Romans, the Arabs, and the Ottomans as well as the European colonizers who arrived in the late $19^{\text {th }}$ and early $20^{\text {th }}$ centuries (Ahmida, 2005: 4, 6-9; Naylor, 2009:15, 35, 57, 109, 141).

To start with the relatively much known incident and long lasting influence in the cultural aspect, the region was conquered by the Arab army of Islamic jihad in $642 \mathrm{AD}$. The introduction of Islam was followed by intense phases of Arabisation mainly because of the migration of two nomadic Arab tribes, Bani Sulaim and Bani Hilal from Egypt and Hejaz during 1050-1100 AD (Raza, 2012: 2; Shillington, 2005: 157).

North Africa became part of the Ottoman Empire beginning from the $16^{\text {th }}$ century. The territories that became the present-day Libya were occupied by the Ottomans in $1551 \mathrm{AD}$ and were governed as part of the Ottoman Empire with much internal autonomy for the next three centuries until 1830. It was reconquered in 1830 by the Ottomans' authority in the fear of the European powers and restored to 1855 (Shillington, 2005: 273-276). Italy was one of the European countries aspiring for the occupation of Libya throughout the last decades of the $19^{\text {th }}$ century. This was because it could not compete for the other African territories as it was the late comer to the scene. By then, Libya was considered as "leftover" that could not attract the other European colonizers (Gooch, 1989: xi-xii). 
Italy, the aspirant of Libya as its colony, was the heartland of classical Roman civilization until its collapse in the $5^{\text {th }}$ century AD. However, it could not be strong enough to be a unified state up to the 1870s. Most of the other European countries emerged as "nation states" after the period of renaissance and series of different aspects of revolutions, particularly, the industrial revolutions. The industrial revolutions led the way for international trades to flourish although not on equal grounds. These international trades finally led to the need for overseas colonies, in fact, along with other important drivers. These drivers can be categorized together as economic i.e., industrial raw materials and markets for industrial outputs. Thus, the industrial states that emerged began to look for colonies in Africa and Asia. Then, most territories in these continents were subjected to colonial occupation (Rodny, 1973). By the end of the $19^{\text {th }}$ century, Britain and France became the leading colonial empires. Relatively speaking, Germany and Italy were the late comers to the race. Even, in comparison to Germany, Italy was an infant state. That was why it took Germany as best model in its efforts of nation or empire building, like establishing modern army. In fact, Italy became a unified state by the second half of the $19^{\text {th }}$ century as did Germany (Gooch, 1989: 202).

Then, the unification of Italy was followed by its strong interest for colonial territories to obtain natural resources and establish colonial settlements (Ahmida, 2005: 41). Since it was the late comer and did not have strong say, Italy was forced to go for the "leftover" territories and even for that it needed the support and recognition of Britain, France and Germany (ibid: 22-24; Tesfaye Gebre'ab, 2017: 158). Some of these "leftovers" were Eritrea, Somalia and Libya. Since the focus of this study is Libya, let us see how Italy attempted to colonize that territory.

Italy's occupation of Libya was a long plan, preceded by emigration of significant number of Italians to that territory. As to Raza, "Italy adopted a gradualist policy of slow economic penetration of Libya, beginning in the late 1800s" (Raza, 2012: 7) even before its official unification. Italian businessmen were supported and encouraged to purchase different concessions and manufacturing interests in Libya. They were also urged to participate in international Libyan trades. The Bank of Roma, Banco di Roma, was ordered by the government of Italy to penetrate into the economy of Libya in 1905. By 1910, the Bank had established more than twelve branches in different Libyan towns and cities. Such economic penetration was to encourage the emigration of Italians to Libya to be employed in those economic enterprises. The migration was followed by the opening of Italian schools and the flourishing of Italian newspapers. Because of this emigration, the total Italian population in Libya became about 27,495 by the end of the first decades of the $20^{\text {th }}$ century (ibid: $5-7$ ). 
After a long process of penetration, Italy began preparing for the armed conquest of Libya by the 1890s. Previously, it assured its occupation of Eritrea still through a long process of pushing in from the Red Sea coast where it founded a base in 1869 . Then, it took Italy or its companies about quarter of a century to establish Eritrea as its colony which was accomplished in 1890. Consequently, it was from this Eritrean territory and northern Ethiopia that Italy began to recruit the colonial soldiers commonly called askaris. The term askaris was derived from the Arabic word "askari" which means "soldier". Currently, it is used with similar meaning in Asian languages like Persian, Turkish, Urdu, Tajik, even Swahili and the like. But in the European colonial history, it is understood as a local soldier serving in the armies of European colonial powers mainly in the northern and eastern Africa. It was used in this sense of local soldier in English and other European languages including the Italian (Scarselli, 2015).

Eritrea particularly Asmara and Massawa began to attract migrants from northern Ethiopia who were looking for employment, to work as laborers after the Italian occupation of that territory. Significant numbers of migrants were also employed as askaris to serve in Libya (Tesfa Mikael, 2006 EC: 21-30).

\section{The Recruitment of Ethiopians and Eritreans as Askaris by Italy}

The recruitment of natives for the purpose of colonial occupation was not special to Italy. All European colonial powers employed askaris from their newly occupied colonies. The Italians did the same since their occupation of Massawa in the 1880s where they met those who could be employed as askaris (Scarselli, 2015: 15). The first recruited men were part of the Egyptian army from Sudan and the Red Sea shores who were serving the Ottomans as irregular soldiers. These were local police forces identified as bashi-bazouk. They served in the Italian army until the battle of Adwa in 1896. The official askaris were established on 28 September, 1888 after a strong suggestion of a military commander, General Antonio Baldissera. Italy recruited significant number of askaris for its attempt to occupy Ethiopia which was routed at the battle of Adwa in 1896. The process of recruiting the askaris was characterized by rise and fall on the number of their battalions. They were increased in number significantly when need arises to about eight battalions and dropped down to about four battalions in 1902 and dramatically increased after 1911 because of prolonged resistances of the Libyans against the occupation (ibid: 18-19). Even if, the battalions were identified as "Eritrean battalions", actually they were from Eritrea and the whole of northern Ethiopia. Tesfa Mikael who was a member of the askaris in the second campaign

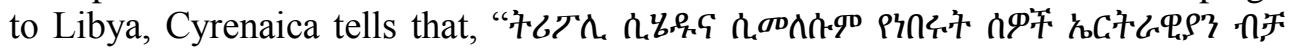




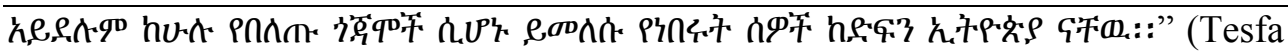
Mikael, 2006 EC: 22). Roughly to mean "Those who went to and back from Tripoli were not only Eritreans; most of them were Gojjames; the returnees were [men] from the whole of Ethiopia". As it is mentioned frequently throughout this article, Gojjam is known for its worst nature of maladministration and excessive taxations during the period of Ras Hailu. The Ethiopians and Eritreans were employed not only for battle fields but also to serve as guards in Italian concentration camps and prisons as well as porters in Libya. Ali Abdullatif Ahmida expresses his experience in Libya as "The guards for the camps were Italian colonial soldiers from Eritrea ..... Eritrean Askaris were Italian subjects who were recruited to serve as a cheap military labor in Libya beginning with the conquest in 1911." (Ahmida, 2005: 48).

\section{Why did the Ethiopians and Eritreans want to be employed as Askaris for Italy?}

Sources indicate that there were several factors that pushed the Ethiopians and Eritreans from their home to Asmara to be employed as askaris. One of the prevalent problems that pushed Ethiopians and Eritreans from their localities was hunger and famines. Migration to Asmara was one way out from the recurrent famines of the late $19^{\text {th }}$ and first half of the $20^{\text {th }}$ centuries. Then, they came across this employment opportunity, askari (Amanuel, 1998: 258-259). Tesfa Mikael describes his experience in Eritrea about this issue as "The government of Italy did not think for the poor, it appreciated the starvation of the people. Why? Because they would be governed in peace and went for the Arab war in Tripoli." (Tesfa Mikael, 2006 EC: 47).

The other related drive, even much more common in Eritrea and northern Ethiopia, because of historical and geographical reasons, was poverty and unemployment. Thus, those who had the objectives of escaping poverty, "กढ 7t1' hC. cows to milk [and] to be free from the yoke of poverty", migrated to Asmara and were employed as askaris for the Italian war in Libya. Hence, a popular song in Eritrea as,

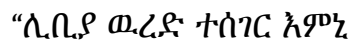

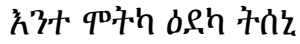

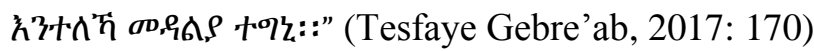

meaning, 
"descend or go to Libya crossing the desert, in case you die, you will be free from your debt; if not you will be prized a medal."

It is also known that "the Tigrians [migrants] in Eritrea were engaged in all sorts of jobs ranging from shoe shine to cactus fruit selling, to hand craft, to the service industry, and in some instances to clerical... positions." (Ghelawdewos, 2017: 3). Then, it was also from these Tigrians who went there for the mentioned occupations that the recruitment was carried out.

Local maladministration, mainly in Northern Ethiopia was also one of the major driving forces. Sometimes, it has been over emphasized as the major cause for the migration and recruitment of the Ethiopians than the Eritreans. It was justified that the recruitment of the Eritreans was linked to colonial pressure but that of Ethiopians was the result of evil deeds of the regional or local governors. Tesfa Mikael, an Eritrean, depicted this fact in his discussion about a dialogue between an Eritrean Fitwurari by the Name Gila Giyorgis and Ras Hailu of Gojjam,

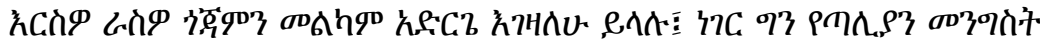
क.

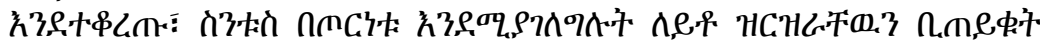

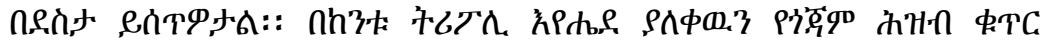

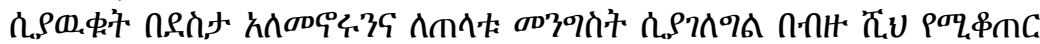

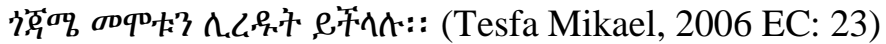

Nearly to mean

You say, I am governing Gojjam well, however, since the government of Italy is your friend, ask how many Gojjames are dying, losing their organs and still serving in the war in Tripoli. The government will give you their list. When you know the number of Gojjames who went to Tripoli and perished in vain, you can understand that they did not live in happiness, rather thousands of them were perished while serving the government of their enemy.

The administration of Ras Hailu was known for its numerous types of taxations in the history of Ethiopia. It is said that he levied poll tax on each male member of the society regardless of their age. As to the same sources, Ras Hailu 32 
was collecting taxes even from the needy (Tekeleyesus, 2002 EC: 209-211). So, it is not surprising that a number of male members of the Gojjames were leaving for Tripoli via Asmara. It was because of this fact that an Italian officer who registered

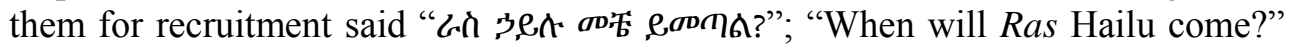
referring that "all the Gojjames are coming" (Mersie Hazen, 1999 EC: 118).

The cultural attitudes of Ethiopians and Eritreans that is, to be a man of battle, warlike culture mainly as to the memoirs of Italian military commanders which were gone through by Aldo Giuseppe Scarselli, was also another driving force for the enlisting of Ethiopians and Eritreans to be employed as askaris (Scarselli, 2015: 24-26). Similarly, Gebreyesus Hailu wrote in his book entitled Conscript (A novel of Libya's anti colonial war) that "why do you wish to fight for a foreigner? What use it for you and your people to arm yourselves and fight overseas? You have all you want, why?". The author gave the answer for such questions as "he [the conscript] resolved to go to Libya to fight as a hero and gain fame" (Gebreyesus, 2012: 7). In fact, the warlike attitude and love to firearms seem common in the culture of Ethiopians and Eritreans. The one who had oxen and cows sold them for a gun. Songs and other related indications are there. Therefore, the Italians provided them with rifles for free, a golden opportunity for the youngsters (Teshale, 1995: 35-37, 51).

The other social factors that initiated youngsters to be enlisted in the recruitment were the news from the returnees of the first Italo-Libyan war (Tripoli), as one of the participants commented, "When my relatives who went to Tripoli in the fifth battalion, visited Rome and come back urged me...." (Tesfa Mikael, 2006 EC: 21). Thus, influenced by their story he was recruited in the $8^{\text {th }}$ battalion of the Ethiopians and Eritrean askaris to Cyrenaica, Aderna in December 1913.

Such social attitude inspired even the small boys to think about a campaign to Libya although they could not be enlisted because of their age as their song indicate:

"Come back to us later Tribuli

Give us time to grow up" (Gebreyesus, 2012: 7).

The sources from the Italian side gave due emphasis for the pulling factors like salary, guns, uniforms and rations. The memoirs of three military commanders, Giovanni Gamerra (officer of the old guards and took part in the early recruitment of the askaris), Errando Di Aichelburg (army trainer who met the askaris not in battle fields but in training camps), Tito Piccirilli (who met the 
askaris in Eritrea and Libya during the counter insurgency),written in Italian language were accessed by the present researcher through Aldo Giuseppe Scarselli who gives us detailed information about the experiences of the commanders with the askaris (Scarselli, 2015: 21-36, 37-40).

There are evidences from the Ethiopian and Eritrean side that support the Italian descriptions. In the earlier history of Ethiopia, the ones that went to war front was not provided with rations (foods and drinks) by the government or his immediate masters. Rather, he had to prepare his provision from his own sources or loot from the peasants who were on the route to the battlefield or located in the

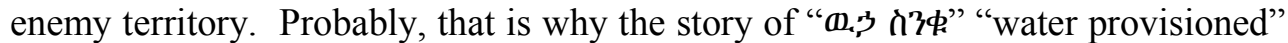
regiment is popular in the military history of Ethiopia. But, recruitment to the Italian government as askaris solved all these uncertainties. The colonial soldiers were provided with all the foods although, the amount and types of food items provided to the colonial army and metropolitan army were different. As the Italians themselves mentioned the colonial army survived on less ration both in amount and quality (Arielli, 2015). Military uniform was also a new experience for the Ethiopian and Eritrean recruits. It inspired the youngsters who could not afford to get European cloth or access to buy (Gebreyesus, 2012: 3; Scarselli, 2015: 22).

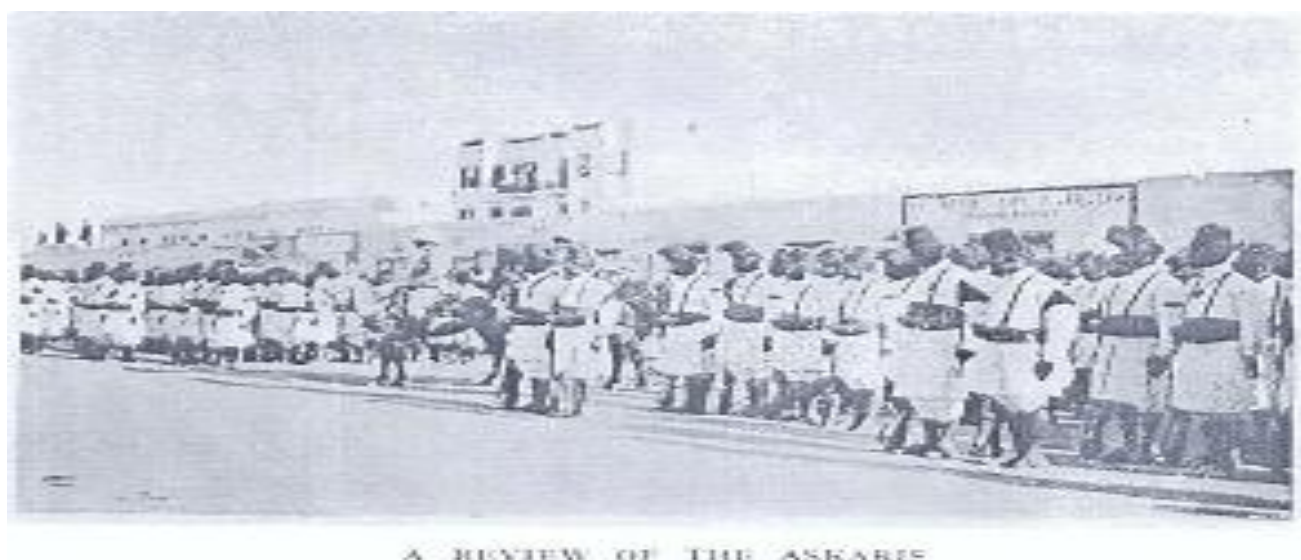

Figure 1: The Ethiopian and Eritrean Askaris with their guns and uniforms Source: W.k. McCure, Italy in North Africa: An Account of the Tripoli Enterprise (London, 1913: 145). 
Regarding ammunitions, guns and bullets were very expensive items that cannot be available easily in Ethiopia and Eritrea during the period under discussion. It was possible to access them without problem by being enlisted to the Italian army as askaris. The Italian military commanders discussed much about the askaris' love for ammunition, commitment to get it in the form of gift from their masters. As quoted in Scarselli“... their real passion is towards firearms: and they make every effort to have them. The officers, knowing how pressing this desire is, donated them as a prize in the circumstances of a reward. And when they have them, they become proud and superb, while the officers that provided the firearms became for them the greatest man on earth.'(Gebreyesus, 2012: 3; Scarselli, 2015: 35). As to the memoirs of these Italian military commanders, the askaris did not want to carry much items when they went to battlefields, they needed to be free. But, this was not true to armaments. They were ready to carry as much as they were provided with. It developed their confidence to win battles (Scarselli, 2015: 34).

The salary paid by the government of Italy was also another attracting factor for the Ethiopians and Eritreans to be employed as askaris. The monthly salary of the askaris was by far better than that of the Ethiopian traditional soldiers' benefits. The traditional Ethiopian soldier got four thalers, a gabi (toga) and surri (a pair of trousers) annually. But, the askaris were paid 50 lire per month, about a total of 600 lire per year (Amanuel, 1998: 255).

The appreciation and trust the askaris got from the Italians were also inspiring the others to be enlisted. They were recognized and appreciated for their military talent and shooting skill (Scarselli, 2015: 33). For instance, they were welcomed by the Italian emperor Victor Emmanuel, military generals and soldiers in Rome on their way back to Asmara from Libya (Tesfa Mikael, 2006 EC: 28). The military commanders mentioned above, added that the army members were at a better social hierarchy than the civilians in Ethiopia and Eritrea. Because of this, when the war in Libya required the Eritrean battalions and made a call for voluntary recruitment, it was gladly accepted. Scarselli quoted from the memoirs:

....at first it was a continuous rush of men that wanted to enlist both to serve under our flag and to fight and those who were recruited for this purpose were considered lucky. Those who left showed an immense joy, not thinking about the sorrow they were causing to their families, wives and mothers with their departure. Those who remained were full of envy and jealousy for the glory that would have occurred to the others (Scarselli, 2015: 25). 
The other pulling factor, particularly for those who were subordinate to someone or slaves, was attainment of relative freedom when they were employed as free men, salaried Italian employee. It was also possible to get protection and safety for the helpless member of the society by joining the Italian army as askaris (ibid: 23-24).

Moreover, the social history of northern Ethiopia was characterized by a number of conflicts and blood feuds. The enmity even among relatives was very critical in the areas where rist $t^{2}$ land tenure system was practiced. This frequent uncertainty forced some of them to be in the hands of powerful master or to look for opportunities that enabled them to own guns. One of the available opportunities during this time was employment as askaris of the Italian (Teshale, 1995: 71-101).

\section{Why did the Italians rely on Ethiopian and Eritrean Askaris for their wars in Libya?}

Organizing or employing askaris to conquer others' territories were common practices in the history of colonialism. The same was true in the colonial history of Italy in Africa. Both the recruiter and recruited had their own respective motives in this case. That of the employees has been described above. The following are some of the factors that led the Italian government to rely mainly on the askaris.

One of these was "political expediency". In comparison to employing Italian soldiers, employing colonial soldiers was more beneficial politically because of its possibility of "loss aversion". The death of colonial soldiers barely had significant political crisis in comparison to that of Italian soldiers. The deployment of Italian soldiers to fight prolonged and steady wars in Africa was not politically effective and economically efficient. That was why the Italians inclined to deploy colonial soldiers, Ethiopians and Eritreans in this case, to their war fronts in Libya. It saved the government from possible "political backlash" that could happen because of the death of numerous Italian soldiers in the war fronts (Arielli, 2015: 53).

Cost was another very important reason for the Italian government to rely on the Ethiopian and Eritrean askaris instead of Italian soldiers. The former were cheaper to maintain than the latter. Sources indicate that the colonial soldiers were recruited on a voluntary basis and considered as "mercenaries". They were

\footnotetext{
${ }^{2}$ It meant the land inherited from ancestors or the land transferred from father to sons or daughters. It was both an ancestral descent claim and effective possession of the land. See (Teshale, 1995: 73) for further explanations.
} 
employed for a two year term, but they were provided with an option to extend their term for another two years. In contrast to the askaris, an Italian soldier was entitled to a basic daily pay of 2.25 Lire, supplemented by a further 3.50 lire per day for services outside his homeland. But an askari was entitled to a basic daily pay of 1.50 lire for the same service during his first two years term and increased to 1.75 and 2.00 during the second and the third term respectively. And the one who was posted outside his country received a further allowance of 1 lira per day (ibid: 53). Therefore, an Ethiopian or Eritrean askari cost the government less than half of an Italian soldier. Moreover, the askaris was allocated fewer rations and could survive effectively on that (ibid: 54 ).

Sources indicated that physical and mental attributes of Ethiopian and Eritrean askaris were also another advantage to rely on for Italy. Contrary to the "master race" theory of the British, the early $20^{\text {th }}$ century Italian officers and military scholars asserted that the Ethiopian and Eritrean askaris were better than that of the Italian soldiers in their level of effectiveness and masculinity. They wrote that the askaris were more suitable to the weather and could overcome the challenges of African topography (ibid).

The other issue that can be taken as part of mental and physical attributes of the Ethiopian and Eritrean Askaris was their loyalty and "their love for waging war and fighting". The Italian officers stressed strongly the "war like attitude of the askaris". This attitude was common to a certain extent throughout the whole of Ethiopia. Warrior hood contributed for promotion, material benefits as well as social respect that were achieved from battlefields, ability to fight and win (Kebede, 1999:167-170). Therefore, Italians used this psychology for their recruitment of Ethiopian and Eritrean askaris. The Italian commanders concluded that an askari is "the man who likes war more than anything else." (Scarselli, 2015: 24). 


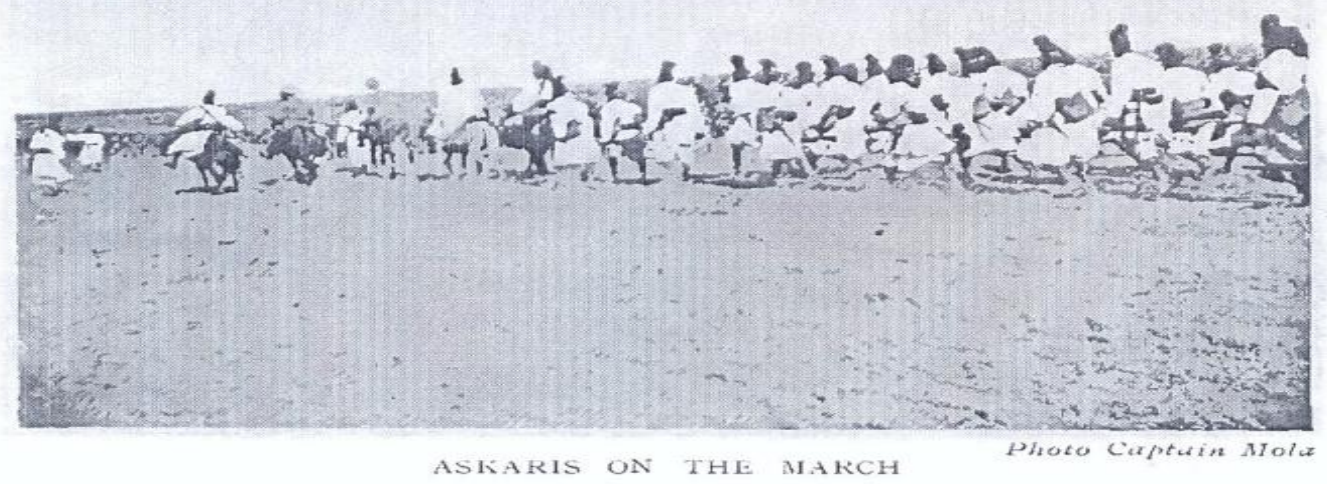

Fig. 2: The Ethiopian and Eritrean Askaris on the March

Source: W.k. McCure, Italy in North Africa: An Account of the Tripoli Enterprise (London 1913: 145).

This idea of "warlike attitude" was also mentioned by Gebreyesus Hailu in his novel entitled "the conscript" that the Habasha felt idle in the absence of war and always pray for war, as "Lord, don't let us be dormant, please bring us war." (Gebreyesus, 2012: 7).

Concerning the loyalty of the askaris, Knud Holmboe, a European traveler in Libya, gives a detailed description on why the Italians preferred the Ethiopians and Eritreans than the Libyans. He wrote what he observed in Cyrenaica as:

"Here [in Cyrenaica] there was no a single Arab soldier; they were all natives from the Italian colony of Eritrea. 'Why don't you use Arab troops?' I asked colonel de Ronco during the evening. 'You can't trust them. They fraternize with the enemy.' 'But are the Eritreans any better?' 'They are more reliable. ..... The Arabs here in Cyrenaica are exceedingly poor soldiers, while we can trust our brave troops from Eritrea implicitly.'..." (Holmboe, 2006: 62-63). 
Moreover, the same traveler asked Lieutenant-Colonel Piatti, stationed at Maraua, "why there were so many troops from Eritrea in Cyrenaica?" the latter replied that the Ethiopians and Eritreans were the only troops that they can depend on. This was because "the Arabs are lazy and unreliable. ....Run away at the slightest provocation.... The Eritreans are absolutely loyal to us."(ibid: 83).

\section{The Role of Ethiopian and Eritrean Askaris in Libyan Wars The First Phase (1911-1912/13)}

The bulk of materials produced by both foreigners and Ethiopian and Eritreans scarcely mentioned the role of the Ethiopian and Eritrean askaris in the first phase of the war (Turko-Italian War). These materials consist of very fragmented information about the role of the askaris even in the other two phases of the Italian wars in Libya.

Italy began to recruit the Ethiopians and Eritreans in Asmara after observing their actual "warlike" attitude and fighting behavior. While discussing the activities of Italian army in different fronts of the Turko-Italian war, an author discussed the condition of Red Sea and vicinity of Suez Canal as "the Italian garrison in Erythrea was reinforced from the 3700 Italian regulars to 10,000 men by recruiting natives." (Beehler, 1913: 25). Mersie Hazen, who had interviewed one of the veterans in this war, wrote a description about the Ethiopian and Eritrean experiences in brief. As to his description, the occupation of Libya by the Italians was strongly resisted by the Libyan Arabs who collaborated with the Turks. This Libyan reaction forced the Italians to recruit askaris in Asmara, from the Eritreans, and migrants from Tigray and Amhara region. The news of Italian recruitment of Ethiopians and Eritreans disseminated throughout Eritrea and Northern part of Ethiopia very soon. Then, a number of individuals were migrating from Tigray, Gojjam, Wollo and even Shewa to Asmara to be employed as askaris (Merse Hazen, 1999 EC: 118; Tesfaye Gebre'ab, 2017: 172). The informant of Merse Hazen told his story as follows:

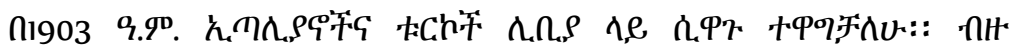

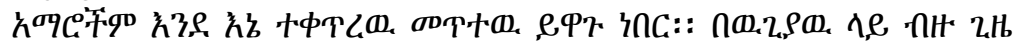

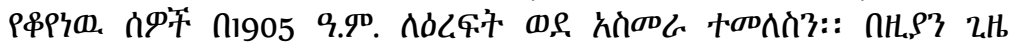

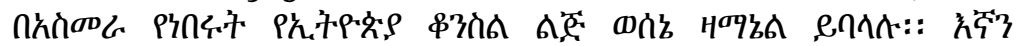

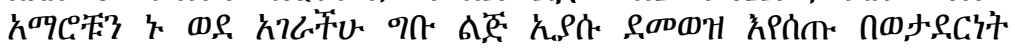

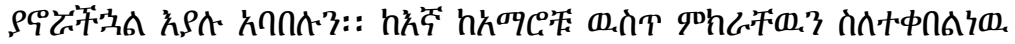

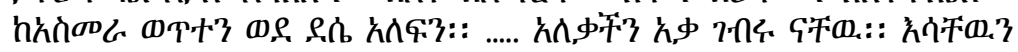

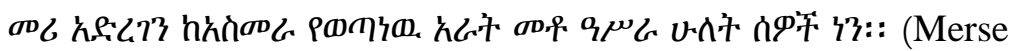
Hazen, 1999 EC: 118) 
which can be translated as:

I fought in the Turko-Italian War in Libya in 1911. A number of Amharas were employed and fought. Those, who were in the war for long time returned to Asmara in 1913. During that time, the consul of Ethiopia in Asmara was Lij Wosenie Zamanuel. He called us, the Amharas, and said come to your country, Lij Iyasu will employ you. Of the Amhara those who accepted his advice left Asmara and came to Dessie. Our commander was Aqa Gebru. Those we left Asmara under his command were four hundred and twelve men.

One can deduce two points pertaining to the number of askaris from the quotation above. The 412 whose number is mentioned here are the ones who served for two years and relived from the fighting. They were only the Ethiopians. Of the Ethiopians, they were only the Amharas. The number does not include the Tigrians. Of the Amharas, the 412 are only those who accepted the invitation of the consul and were ready to be employed as Iyasu's police force, Trinbulee $e^{3}$. Thus, we can assume that only from one batch of Ethiopians who volunteerd to come to the palace of Lij Iyasu of which only the Amhara, were about 412. So, it can be estimated that the total number of one batch (battalion) might be near a thousand. Of course, Aldo Giuseppe Scarselli mentioned that “... on the first February of 1912 the recreated $5^{\text {th }}$ Eritrean battalion left Massawa for Tripoli...The $5^{\text {th }}$ battalion with one thousand one hundred men was not only the first to be deployed in Libya; it was also the first indigenous battalion to reach Italy." (Scarselli, 2015: 20).

Regarding the appearance and psychological readiness of this battalion, an observer who saw them on their arrival in Tripoli depicted that:

The askaris are very alert and soldierly-looking men, tall and spare with a splendid carriage, some straight- featured and copper- coloured, others of the black Sudanese type. They brought a good reputation from Eritrea, and they were to show themselves useful scouts and staunch fighters. Their mobility is

\footnotetext{
${ }^{3}$ It was the name of police force established during the reign of Lij Iyasu recruited from the returnees who fought in the Libyan war. Their name is a distorted form of Tripoli, Libyan capital.
} 
remarkable, running bare-footed in the sand, they are able to operate with cavalry, and their endurance is not less noteworthy than their speed (McCure, 1913: 144).

The confrontation made between the Ethiopian and Eritrean battalion, and the enemy on March 3 and 4, 1913 created a strong impression and confidence among the Italian military officials. It was explained from the Italian side as the askaris could defeat in their first battle with the Libyans who had a strong force near Bir el -Turki. They also forced the Arabs to retreat to the desert in their next battle described as "the Arabs melted into the desert". The Italian officers were "proud of them" and they were "congratulated" by the government of Italy because of such successive victories (ibid).

On the other hand, the Libyan source described it as "A battalion of askaris and a camel riding detachment arrived from Erythrea late in February, and was vigorously attacked by Arabs on March 4 at Bir-el-Turki, the askaris were routed, and only managed to escape into Tripoli under cover of darkness with heavy losses."'(Beehler, 1913: 163).

Even if it is not clear from these sources who were victorious, it can be understood that the Ethiopian and Eritrean askaris fought in Libya in those battles. This first phase of the wars was fought for a year without significant victory from both sides, except the Italian aggressive atrocities on the Libyans in many cases. Then, both of them were ready to a peace treaty because of their respective reasons. On the Italian side, they were fed up of fighting that prolonged war which even took the character of a jihad war. It was extremely costly for the Italians both in manpower and finance. Meanwhile, Turkey was also occupied with many resistance wars in most of its colonial territories. Especially, the challenge it faced in the Balkans at that time forced the Ottomans to arrange the condition of their last strong holds in North Africa, Libya (Tesfa Mikael, 2012: 22).

Thus, the overall situations resulted in the withdrawal of the Turkish force from Libya. Unfortunately, it could not bring either peace to Libya or total control of the country by Italy. Rather, it resulted in the opening of the guerilla resistances of the Libyans against Italy under the Sanusi order. This resistance movement began in 1913 and continued for the next decade all through the course of the First World War (ibid: 23-28).

\section{The Second Phase (1913-1922)}

As it has been mentioned above, the withdrawal of Turkey from Libya could not bring peace. Rather it resulted in the disappointment of Libyan Arabs thinking that 
Dechasa Abebe

they were left in the hands of the "infidels". Thus, they opened a strong war of resistance against the Italians' and launched large scale attack to expand their control of Libya. However, the Italian soldiers were fed up of this prolonged war in Libya. They were not courageous enough to fight against the courageous jihadist Libyans. As a result of this and other cost related reasons, the Italians began to recruit askaris again, the $8^{\text {th }}$ battalion, because of the experiences they got from the previous battalions, particularly, from the strengths and efficiency of the $5^{\text {th }}$ battalion who fought in the Turko-Italian War in Libya (Tesfa Mikael, 2006 EC: 21).

Historical sources indicate that a number of Ethiopians and Eritreans were recruited in the $8^{\text {th }}$ battalion from the migrants in Asmara. Those askaris in this battalion were exceeding in their fighting skill and courage. While, the Italian soldiers were terrorized by the acts of Libyan Arabs who beheaded the captives, the Ethiopians and Eritreans were bold enough to confront the Libyan Arabs and able to defeat or die without fear (ibid: 25). Italy continued to recruit the Ethiopian and Eritrean askaris, and formed the $10^{\text {th }}$ battalion. Up on the withdrawal of the $8^{\text {th }}$ battalion from war fronts after 9 months, the Italians deployed the already recruited $10^{\text {th }}$ battalion (ibid: 26 ).

Italy fought for about three to four years continuously to crush the resistances of the Sanusi of Libya. However, to its detriment, it began having financial problems. Then, Italy plan to make truce with the Sanusi leaders of Libyan Arabs. Accordingly, beginning from 1916 to 1920, about three different accords were signed. These were identified as treaties of al-Zawaytina (1916), al-Akramah (1917) and al-Rajma (1920) (Raza, 2012: 29-31). Unfortunately, these accords between the two were tactical and to buy time, rather than for ultimate peace. Thus, relations between the two deteriorated and led to the third phase of ItaloLibyan War; mainly after 1922 (ibid: 31-32).

\section{The Third Phase (1922-1932)}

Like in the first and second phases of the Italo-Libyan wars, the Ethiopian and Eritrean askaris played a significant role, in the third phase of the wars, even more in this case. The work of Arielli is informative in this aspect although it deals with all the four categories of askaris together; Libyans, Ethiopians, Eritreans, Somalis and Yemenites. In fact, the East African askaris were frequently identified as "Eritreans" altogether in the sources simply because of the Italians familiarity with their colony of Eritrea (Arielli, 2015: 54). Still, the number of Yemenites and Somalis were insignificant. The Italian military commanders had no confidence in Libyan Arabs as mentioned above. Subsequently, most of the askaris were 
Ethiopians and Eritreans, identified as Eritrean battalions or mixed battalions. Any ways, one can understand to what extent Italy relied on the askaris for its colonial wars in Libya from the following table adopted by Arielli from the archive of Italian Ministry of Foreign Affairs.

\begin{tabular}{|l|l|l|l|l|l|}
\hline Year & $\begin{array}{l}\text { Colonial } \\
\text { troops }\end{array}$ & $\begin{array}{l}\text { Italian } \\
\text { troops }\end{array}$ & Year & $\begin{array}{l}\text { Colonial } \\
\text { troops }\end{array}$ & $\begin{array}{l}\text { Italian } \\
\text { troops }\end{array}$ \\
\hline $1914-15$ & 19,000 & 50,500 & $1921-22$ & 23,100 & 4,500 \\
\hline $1915-16$ & 14,000 & 61,000 & $1922-23$ & 31,600 & 1,900 \\
\hline $1916-17$ & 18,000 & 48,000 & $\begin{array}{l}\text { December } \\
1924\end{array}$ & 23,792 & 11,223 \\
\hline $1917-18$ & 18,000 & 48,000 & $\begin{array}{l}\text { December } \\
1925\end{array}$ & 23,990 & 13,163 \\
\hline $1918-19$ & 18,500 & 57,000 & $\begin{array}{l}\text { December } \\
1926\end{array}$ & 22,723 & 14,130 \\
\hline $1919-20$ & 21,500 & 25,000 & $\begin{array}{l}\text { September } \\
1927\end{array}$ & 25,820 & 17,448 \\
\hline $1920-21$ & 21,300 & 5,700 & $\begin{array}{l}\text { November } \\
1928\end{array}$ & 28,558 & 12,672 \\
\hline
\end{tabular}

Table 1: Troops Stationed in Libya, 1914-1928

Source: Nir Arielli, "Colonial Soldiers in Italian Counter-Insurgency Operations in Libya, 1922-32" in British Journal for Military History, Volume 1, Issue 2, February 2015, University of Leeds. Available at www.bjmh.org.uk

It is possible to infer the proportion of Ethiopians and Eritreans from this table; even if, it is difficult to indicate their exact number. This is because Italy did not have vast colony during the WWI unlike other Europeans who could recruit askaris from their vast and different colonies. Similarly, it is also possible to understand the rise in the number of the askaris first gradually and then dramatically in different years. In this aspect, there were several landmarks. For instance, there was a sudden drop in 1915-1916, during the high time of WWI, 
because Italy was over stretched by the European war and signed accords with the Libyans to make truces (Raza, 2012: 29). Of course, by 1916 Italy sent Ethiopian and Eritrean army to Libya so that it relieved its white troops from its war in Libya. That was because the Italian soldiers had a responsibility to fight in WWI, particularly in north Italy (Arielli, 2015: 52). And probably that was why the number of colonial armies increased by 4000 . The other landmark was the end of WWI. By the end of the war, Italy could not send a large number of metropolitan armies to Libya because of the arrangements in the Paris Peace Conference and the heavy losses of Italy during the war. So, the number of metropolitan armies in Libya dropped from 57, 000 to 25,000 and to 5000 after a year whereas that of the askaris increased from about 18, 500 to 21,500 (by about 3000). Generally, the end of WWI was followed by a sudden drop in the number of metropolitan armies from about 57,000 in 1919 to 1,900 in 1922 . On the other hand, the number of colonial soldiers which was about 18,500 in 1919 rose to about 31,600 by 1922 . The increase was because of the fact that the operation of re-conquest of Italy in Libya in 1922 was heavily relying on colonial troops; i.e, Eritrean battalions, and Libyan collaborators (ibid: 53).

During this phase of the wars, the Eritrean battalions played a very important role in crushing the Libyan resistances. As mentioned in Arielli, they were praised as marchers, especially in mountainous terrain. The commanders reported that with them it was possible to cover $50 \mathrm{kms}$ in a day. Their arrival in a battlefield, even a small one, could often decide the fate of that battle. They were identified as "excellent warriors". The Italian military commanders were convinced that Eritreans were the key to crush the revolt in Cyrenaica in the summer of 1930 (ibid: 55).

Generally, Italy had employed a significant number of the Ethiopian and Eritrean askaris from the late months of 1912 to 1934. Sources indicate that about 68 battalions and six artillery batteries were serving in rotation in Libya throughout the course of the wars. This was even to the extent of resulting in the scarcity of labour force in Eritrea by which an Italian official commented that "Eritrea must not be reduced in to a 'seedbed' of askaris for the other colonies" (ibid: 56). As a result, the Italian colonial governors in Eritrea issued restrictive measures in its enrolment regulations to discourage the Eritrean recruitment that resulted in scarcity of labour force in Eritrea. Then, this opened the way for Ethiopians to be recruited replacing the Eritreans. Thus, there was mass enrolment of people from Tigray, Amhara, Gojjam, Shewa and the Oromo region. Surprisingly, there happened to be a settlement of people from Gojjam, Shewa and the region of the 
Oromo in such Eritrean colonial towns as Ghinda, Nefasit and Keren from those who moved into Eritrea to get enlisted as askaris (Amanuel, 1998: 258).

Of course, the armies that were sent from Eritrea also began to be renamed as "mixed battalions" because the large proportions of them were recruited from areas outside Eritrea proper. The vast majority of them were from northern Ethiopia, where Italian sources indicated it as "Amhara" and from Tigray as mentioned above. For instance, from the battalions consisting of 4,301 men sent to Libya in 1924-25; 3,540 were recruited from the spaces outside Eritrean border, most likely from northern Ethiopia (Arielli, 2015: 57; Scarselli, 2015: 20). Because of this, the Italian colonial officials commented that

The Ethiopian regent, Ras Tafari (soon to become Emperor Haile Selassie) is willing to turn a blind eye to Italian recruitment for the time being. However, at the same time he centralized the power of the state and created a national army. Hence the ability to recruit in Ethiopia could dry up completely if tensions between Italy and Ethiopia are to rise (Arielli, 2015: 57).

The Italian colonial officials went to the extent of imploring Mussolini so that he avoided any action that disappointed Ras Teferi until the occupation of Libya should be accomplished properly. This was because there would be a possibility for Teferi to cut the flow of Ethiopian recruits (ibid).

\section{The Consequences of the Libyan wars}

The Italian colonial policy was an extremely brutal in the history of colonialism. Its practices both in Libya and East Africa could not attract the hearts and minds of the colonized people. That was partly why Italy could not pacify both Libya and Ethiopia for long during the occupations. The Libyan Arabs were fighting for decades against the Italians. Similarly, Ethiopians were also fighting against them throughout the five years of their occupation. A great proportion of the society developed strong antipathy against everything Italian and their collaborators both in Libya, Eritrea and Ethiopia (Amanuel, 1998: 259). This hostility of Libyans against Ethiopia and Eritrea during their presence in East Africa as Italian collaborators was really strong. They identified the Ethiopian and Eritrean askaris boldly as "slaves purchased with money to subjugate our country to Italy." (Tesfa Mikel, 2006 EC: 25).

Even some members of the Eritrean askaris who returned from Libya felt that the Italian victory in Libya brought great shame and sorrow to the Eritreans. They 
expressed their feeling as, "the Arabs fight for this barren land." However, the Eritreans could not fight properly to defend their "beautiful land". They condemned themselves saying that "A curse be upon us... we let our country be taken, and we were instruments to occupy someone else's land" (Gebreyesus, 2012: 41-42). It was also commented that by becoming instruments to occupy someone else's country the Ethiopians and Eritreans were committing serious crime that could backfire against them (ibid: 29).

In fact, it really backfired against the Ethiopians after a decade or so when the Italians invaded the country. The Italians placed the Libyan children, between the age of 6 and 15, who were orphaned during the wars in Libya, in special camps to train or bring them up on military lines. They were enrolled to $7^{\text {th }}$ and $9^{\text {th }}$ battalions of the new force by 1934 when their maximum age limit was 18. This Libyan division is well remembered in Ethiopia because of taking no prisoners of war captives; they executed all the Ethiopian captives as vengeance for the Ethiopians and Eritreans who fought in Libya and resulted in the death of their parents (Arielli, 2015: 65-66).

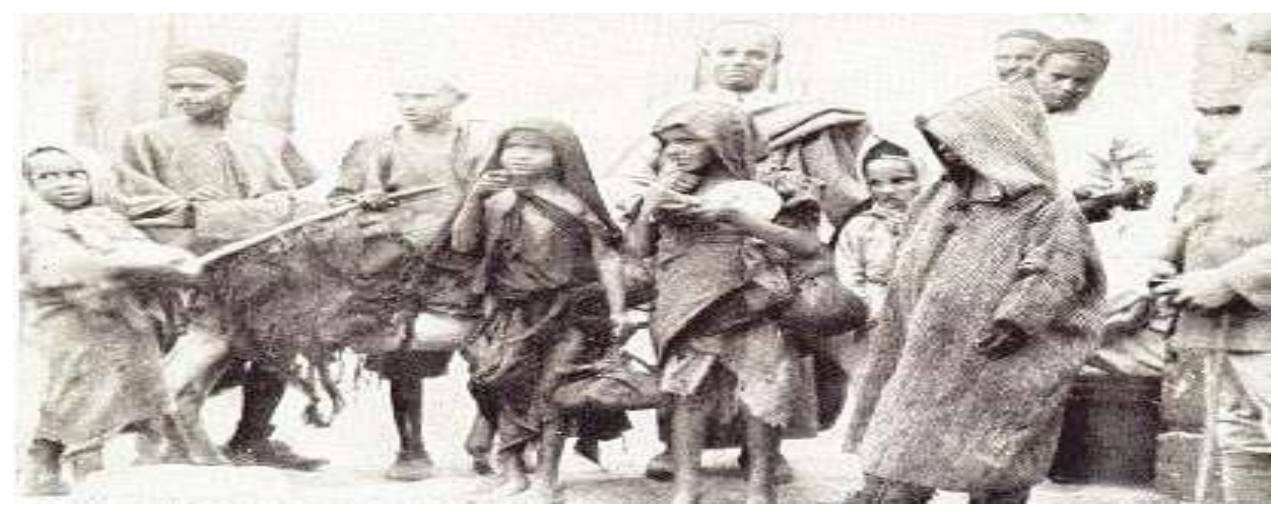

Figure 3: Orphans of Libyans killed in the war

Source: Knud Holmboe, Desert encounters: An Adventurous Journey throughout North Africa (Planet earth, 2006: 70).

The wars also resulted in apparent religious hostility between the Habesha and Libyans which was vividly prevailed during the Italian wars both in Libya and East Africa. The Danish traveler that is mentioned above carefully observed and recorded the prevailing religious enmity in the Italian concentration camps and prisons in Libya. He reported about his communication with a Libyan prison guard 46 
in Derna. The guard expressed his feeling to him as "Don't you think it is better to have Moslems to look after the prisoners than Eritreans? When no Italian officers are about, we can see that the prisoners have an easier time" (Holmboe, 2006: 120). But, the Italians prefer to employ the Eritrean guards. This measure was understood by the Libyan prisoners as an extra punishment. The traveler claimed that they told him, "Do you know why the Italians are using Eritrean troops, because the Eritreans are Christians". Thus, it is possible to conclude that the Libyans believed that they were fighting a religious war in Cyrenaica and every Christian was their enemy (ibid).

Of all, the major consequence of the Libyan wars was loss of material and human resources. The Ethiopians and Eritreans who participated in the wars as askaris were victims of such destructions. This Tigrigna song which was translated into English by Amanuel Sahle indicates the real situation that was prevailing in Northern Ethiopia and Eritrea during the wars or after.

"The train has come covered with smoke we are crying in vain for our missing sons for the train brings to Asmara only the lucky ones who had escaped deaths in the Libyan war."(Amanuel, 1998: 258).

The train here was the one that transported the askaris to Libya, bringing back those who escaped death in the war fronts and the news about those who died in Libya. Here is similar song that expresses popular laments for those who died in Libya.

"One by one our boys are sent to their early graves" (ibid).

As a result, the people requested the clergy to react against the enthusiasm of their youth for the recruitments as:

“Our priests! why don't you speak out?

Not even one young man can be found,

All have gone to Tripoli" (Gebreyesus, 2012: 26).

Even the askaris themselves were said to express their possible fate in Libya in their songs as:

Good-bye, my land, I'm going to Tripoli. 
Dechasa Abebe

I have left my fertile land

Left my home behind

Left the evergreen trees

The sparkling streams

Of the world of my youth

Though fragrant breezes from the valley

Embrace my heart and soul

Yet will I march to the unknown land.

To die and rot on those scorching sands [of Libya]" (ibid: 13;

Amanuel, 1998: 259).

The oversea travel of the askaris from the Red Sea to Libya was full of challenges and accidents. A number of them faced destructive ship wreck. One of such accidents happened to a ship Regina Elena that was transporting about 500 askaris of the $7^{\text {th }}$ battalion in the Mediterranean Sea probably in 1923. Of the 500 askaris only few of them survived from the accident (Tesfaye Gebre'ab, 2017: 173). Moreover, the askaris who took part in those wars in Libya faced another related problem on their way back home. For instance, at one instance about 60 askaris fall sick and taken to a hospital. Of these 60 , about 3 or 4 died every day; those who were not killed in the war and seemed strong were killed there in the hospital "intentionally". An eye witness account mentions it as "

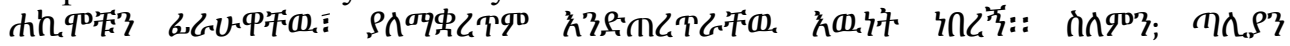

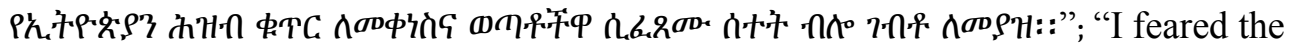
doctors more; I suspected them since I have my own truth. Why? Italy aspired to diminish the number of Ethiopian youngsters and when they finished [perished] it will enter [to the country] without problem." (Tesfa Mikael, 2006 EC: 29). Besides this, theft and plunder in different urban centers in Italy, like in Naples and Rome were also the other challenges that hindered their safe arrival at home. (ibid: 28).

Safe arrival to home area was not the end of the problem for many of the returnees. They were also expected to pay taxes from what they earned in Libya after entering the territory of their respective homelands (ibid: 22). Moreover, the money they brought could not be spent for escaping the chronic poverty mentioned above in most cases; rather it was spent for daily food. And that was why the people were said to sing as:

"The son has gone to Libya to seek fortune

His father spent it all on food

Our tongues are alive indeed 
It is our sense of pride that is dead" (Amanuel, 1998: 259).

Contrary to all the negative consequences, the wars also resulted in some positive outcomes. The askaris were in the same battles and could understand the overall status and fighting skill of the white soldiers. This exposure developed their confidence and removed the inferiority feeling. Furthermore, it improved their consciousness; the Ethiopians and Eritreans were freed from the perception that the Italians are peoples with special knowledge and skill (Tesfa Mikael, 2006 EC: 31; Tesfaye Gebre'ab, 2017: 176). The askaris also observed that the Italians feared the Libyan soldiers extremely. As a result, they began to assume Italians as "cowards" (ibid: 21). As indicated in the following excerpt, the askaris also came across the prevalence of the "backwardness" and the "rudeness" of some members of the Italian society in and around Napoli.

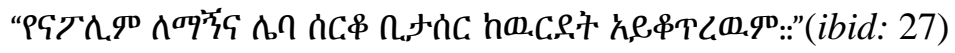

which nearly means,

"The thieves and beggars of Napoli were not ashamed of their crime when they were jailed because of that."

Particularly, the prevalence of theft, prostitutions, and poverty as well as begging in the area developed a sort of confidence in the minds of the askaris, since the Italians were not as they boasted here in Africa or Ethiopia.

\section{Conclusion}

European Colonial powers mobilized African askaris against the Africans themselves during their invasion of the continent in the $19^{\text {th }}$ and early $20^{\text {th }}$ centuries. Similarly, Italy employed Ethiopians and Eritrean askaris for their colonial wars in Libya. It would have not succeeded in its occupation of Libya in the absence of the askaris. This was because of several reasons. Economically, Italy could employ the askaris with less cost that spared their modest economy. Ecologically, the Ethiopians and Eritreans were ideal for the topography and desert climate of Libya which was too harsh for the Italians to overcome. Politically, the war and death of Italian soldiers would have resulted in opposition against the colonial policy at home in Italy. The employment of Ethiopians and Eritreans as a substitute could avert the possible political crisis in Italy since no one worried about the death of these askaris except their poor families. Moreover, the 
Ethiopians and Eritreans were courageous enough and committed in contrast to the Italians to fight in the wars. In fact, they were eager to fight in the desert not in vain. Rather, a number of factors forced them to leave their home knowing that they would die in a foreign desert fighting the others' wars. Poverty, hunger and famines, and love for firearms can be mentioned as the major factors among others. Consequently, their campaign for foreign wars resulted in several social crisis in their home area. More than anything else, the wars led Libyans to develop chronic hatred for Ethiopians and Eritreans. Of course, it was one of the successful Italian missions of employing the Africans against the Africans. 


\section{References}

Ahmida, A.A .2005. Forgotten Voices: Power and Agency in Colonial and Post colonial Libya. London: Rutledge.

Amanuel, S. 1998. "A brief historical survey of the Ethiopian Askaris (National colonial soldiers)" in Proceedings of the eighth International Conference of Ethiopian Studies, 1(1). Addis Ababa.

Arielli, N. (2015). "Colonial Soldiers in Italian Counter-Insurgency Operations in Libya, 1922-1932" British Journal of Military History, 1(2). Retrieved from: www.bjmh.org.uk

Beehler, W.H .1913. The History of the Italian-Turkish War, September 29, 1911 to October 18, 1912. Annapolis.

Gebreyesus, H. 2012. The Conscript: A Novel of Libya's anti Colonial war. Athens.

Ghelawdewos, A. 2017. Wrong is Dead Wrong on Horn of Africa Brothers. Retrieved from Institute of Development and Education for Africa Website http://www.africanidea.org/wrong_dead.html

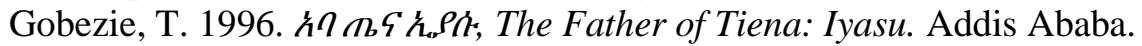

Gooch, J. 1989. Army, state and Society in Italy, 1870-1915. Palgrave Macmillan.

Holmboe, K. 1941. Desert encounters: An Adventurous Journey throughout North Africa. London.

McCure, W.K. 1913. Italy in North Africa: An Account of the Tripoli Enterprise. London: Constable and company, ltd.

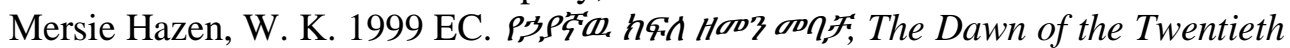
Century. Addis Ababa.

Messay, K. 1999. Survival and Modernization, Ethiopia's Enigmatic Present: A Philosophical Discourse. Trenton: Red Sea Press.

Naylor, C. P. 2009. North Africa: A History from Antiquity to the Present. Austin: University of Texas Press.

Raza, S. 2012. "Italian colonization and Libyan resistance the Al-Sanusi of Cyrenaica (1911-1922)." Ogirisi: a new Journal of African studies, 9. http://dx.doi.org/10.4314/og.v9i1.1

Rodny, W. 1973. How Europe Underdeveloped Africa. London.

Scarselli, A.G. 2015. "The Eritrean Askari believes to be the best soldier in the world!" How the Eritrean colonial soldiers were represented in Italian military memoirs (Master of Colonial and Global History). Leiden University.

Shillington, K. 2005. History of Africa. Palgrave, Macmillan.

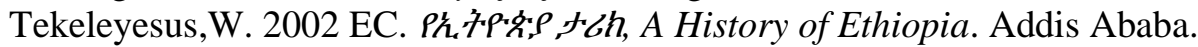


Dechasa Abebe

Tesfa Mikael, T. 2006 EC. Uno Py,ew $\mathbf{b}$ TG, My Country: the Call of my life. Addis Ababa.

Tesfaye, G. 2017. Pr.C 3ח oqV?PC, Nur Al Nebi's File: Espionage and Politics. USA. Virginia.

Teshale,T. 1995. The Making of Modern Ethiopia 1896-1974. Lawrenceville.

Vecchi, Paolo De. 1912. Italy's Civilizing Mission in Africa. New York. 